\section{Drug shortage: a public health problem}

\author{
Descontinuação de medicamentos: um problema \\ de saúde pública
}

\author{
Discontinuación de los medicamentos: \\ un problema de salud pública
}

${ }_{1}$ Fundação Hospitalar do Estado de Minas Gerais, Belo Horizonte, Brasil.

2 Instituto para Práticas

Seguras no Uso de

Medicamentos, Belo

Horizonte, Brasil.

3 Faculdade de Farmácia,

Universidade Federal de

Minas Gerais, Belo Horizonte,

Brasil.

Correspondence

M. B. Rosa

Instituto para Práticas

Seguras no Uso de

Medicamentos.

Av. do Contorno 9215

Belo Horizonte, $M G$

31110-063, Brasil.

mariobr_ca@yahoo.com

Mário Borges Rosa 1,2

Adriano Max Moreira Reis 3

Edson Perini 3

Gaps in access to medicines due to drug shortages create a serious public health problem 1 . In Brazil, such gaps are commonly reported as "lack of medicines". Some research articles refer to the problem as "drug supply failure", specifying flaws in the complex system of measures to support the consumer chain for medicines ${ }^{2}$. Health surveillance refers to the problem as "drug shortage" 3 . This definition offers a more comprehensive idea that the supply failure whether occasional or permanent for the given product, jeopardizes the chain of care despite policy and logistic improvements in the organization of pharmaceutical assistance.

Drug shortage is a global problem 4 that has increased in Brazil in the last decade, interfering in all levels of care, both public and private, from primary to specialized care. As a complex and multifactorial phenomenon, it is influenced by elements of pharmaceutical logistics and diverse political factors, from broad definitions for the health and science and technology sectors to quality of action in the customs, fiscal, and health regulatory agencies 1,2 . During a shortage, the drug's duality becomes evident: as a health product, subject to health regulation in its production, marketing, and consumption, and as merchandise, or part of the international financial system as high added-value commodities with high economic risk. In either situation, shortages involve high political interests, since health infringements or problems with expected profits can jeopardize the supply chain, limiting or even entirely impeding the drug's availability to patients.

In the complex determination of drug shortages, production involves technical and economic issues that interlink in a network of factors. Technical factors include irregularity in the supply and quality of inputs and the inadequacy of good practices $5,6,7,8$. Such factors can lead to the interruption of production or recall of drugs from health services, a problem aggravated when there are only one or a few suppliers of a given drug 6 . Countries that are heavily dependent on technology from the international market are more vulnerable to supply problems 2 . Although Brazil is one of the world's largest markets and currently has advanced regulatory and regulation instruments for production, importation, and guaranteed access, the country is still dependent on technology and the supply of inputs from abroad. Only systematic linkage of research and development policies for production throughout the chain and guaranteed access can reduce this vulnerability. This linkage is especially important for protecting supply against economic factors, including stoppages or cutbacks in production due to low financial returns, new economic plans in pharmaceutical companies, or production line changes due to mergers of laboratories 2,9.

All these factors come under government control in one way or another, and specific sector policies offer more complex explanations 
for shortages and the factors in which government is better able to provide more effective solutions. In technical or economic problems in production and distribution, governments have limited forecasting capacity but can establish focused, short-term measures. Thus, pressured by drug shortages, in 2014 the Brazilian Health Regulatory Agency (Anvisa) published a ruling for dealing with temporary and definitive drug shortages ${ }^{3}$. However, due to weaknesses in the health and science and technology sector policies, shortages are an ever-present risk. Welllinked policies in these areas are essential for Brazil to develop its technological base for the production and absorption of new technologies.

Another fundamental requirement is information. A link on the Anvisa website concerning specific drug shortages helps health services and professionals identify the problem, thereby facilitating the elaboration of intervention strategies. However, this Anvisa link still operates passively, and the agency needs to improve its communication strategies, actively reaching health services, patients' associations, representative organizations of service providers, health professionals' technical and scientific societies, and consumer defense bodies.

Given the negative impact of drug shortages on the health system, Anvisa has acknowledged the importance of monitoring links in the supply chain and establishing short and long-term plans to mitigate the problem. Anvisa's role is increasingly important in regulating drug manufacturing conditions and managing conflicts in the pharmaceutical industry. Such conflict management involves definitions concerning the essential nature of the drug in strategic planning for supply maintenance, signaling opportunities for the contribution by the public and private pharmaceutical industry to develop its production plans to simultaneously guarantee and maintain its economic return and growth and responsible action to meet its social role.

As for consequences, drug shortages jeopardize quality of health care, patients' treatment outcomes and safety, and adherence to clinical protocols, besides increasing treatment costs $1,10,11,12,13,14,15$. For example, the control of gestational and congenital syphilis in Brazil has been affected negatively in recent years by the shortage of benzathine benzylpenicillin and benzylpenicillin potassium 12,13 . In early 2016, epidemiological surveillance measures for communicable diseases were also jeopardized by the shortage of immunobiologicals. Hospital infection control programs were affected by the lack of antimicrobials. All these problems could have been avoided or mitigated by government measures allowing effective linkage between more accurate forecasts of drug supply and immediate interventions, whether through directing production by government laboratories or linkage with the private system, or in the final analysis in planning substitutions or importing the products.

Importantly, substitution during a drug shortage is a complex process that involve risks to patient safety, since medication errors and adverse drug reactions are more likely when a treatment approach is replaced for reasons other than clinical needs 11,16. In this complex scenario, a shortage increases patient care costs, given that the alternative treatments are usually more expensive; during low supply or reduced competition, prices tend to increase 17,18,19.

\section{Contributors}

All the authors participated equally in the manuscript's production. 
1. Pauwels K, Simoens S, Casteels M, Huys I. Insights into European drug shortages: a survey of hospital pharmacists. PLoS One 2015; 10:e0119322.

2. Reis AM, Perini E. Drug shortage: determinants, consequences and management. Ciênc Saúde Coletiva 2008; 13 Suppl:603-10.

3. Agência Nacional de Vigilância Sanitária. Resolução da Diretoria Colegiada - RDC no 18, de 04 de abril de 2014. http://bvsms.saude.gov.br/bvs/saudelegis/anvisa/2014/rdc0018_04_04_2014_rep.pdf (accessed on 10/Feb/2016).

4. Gray A, Manasse HR. Shortage of medicines: a complex global challenge. Bull World Health Organ 2012; 90:158-158A.

5. Agência Nacional de Vigilância Sanitária. Descontinuação de medicamentos. http://portal.anvisa. gov.br/wps/content/Anvisa+Portal/Anvisa/Inicio/ Medicamentos/Assunto+de+Interesse/Descon tinuacao+de+Medicamentos (accessed on 16/ Feb/2016).

6. Machline C, Amaral Júnior JBC. Avanços logísticos no varejo nacional: o caso das redes de farmácias. RAE - Revista de Administração de Empresas 1998; 38:63-71.

7. Kaakeh R, Sweet BV, Reilly C, Bush C, DeLoach S, Higgins B, et al. Impact of drug shortages on U.S health systems. Am J Health Syst Pharm 2011; 68:1811-9.

8. Kaposy C. Drugs, money, and power: the Canadian drug shortage. J Bioeth Inq 2014; 11:85-9.

9. Clarizia N, Lin T. National pharmaceutical drug shortage. http://www.cfms.org/attach ments/article/163/National\%20Pharmaceuti cal\%20Drug\%20Shortages\%20Sept\%202014.pdf (accessed on 16/Feb/2016).

10. McKeever AE, Bloch JR, Bratic A. Drug shortages and the burden of access to care: a critical issue affecting patients with cancer Clin J Oncol Nurs 2013; 17:490-5.
11. Fox ER, Sweet BV, Jensen V. Drug shortages: a complex health care crisis. Mayo Clin Proc 2014; 89:361-73.

12. Ministério da Saúde. Nota informativa no 06/2016/GAB/DDAHV/SVS/MS sobre aquisição de penicilina potássica ou cistalina. http:// www.infectologia.org.br/wp-content/uploa ds/2016/02/1454520212_situao_sifilis_desabastecimento.pdf (accessed on 20/Feb/2016).

13. Ministério da Saúde. Nota informativa conjunta no 109/2015 GAB/SVS/MS e GAB/SCTIE/MS. http:// www.aids.gov.br/sites/default/files/anexos/legis lacao/2015/58575/nota_informativa_109_assina da_pdf_20349.pdf (accessed on 19/Feb/2016).

14. Bosso JA, Kokko H. Assessment of the impact of an antibiotic shortage: patient outcomes and cost. Hosp Pharm 2004; 39:43-6.

15. Gundlapalli AV, Beekmann SE, Graham DR, Polgreen PM; Infectious Diseases Society of America's Emerging Infections Network. Perspectives and concerns regarding antimicrobial agent shortages among infectious disease specialists. Diagn Microbiol Infect Dis 2013; 75:256-9.

16. Institute for Safe Medication Practices. Drug shortages: national survey reveals high level of frustration, low level of safety. https://www.ismp.org/ newsletters/acutecare/articles/20100923.asp (accessed on $14 / \mathrm{Feb} / 2016$ ).

17. American Society of Health Syst Pharmacists. ASHP guidelines on managing drug product shortages. Am J Health Syst Pharm 2001; 58:1145-50.

18. Integrity of the pharmaceutical supply chain: product sourcing for patient safety. Am J Health Syst Pharm 2004; 61:1889-94

19. De Weerdt E, Simoens S, Hombroeckx L, Casteels M, Huys I. Causes of drug shortages in the legal pharmaceutical framework. Regul Toxicol Pharmacol 2015; 71:251-8.
Submitted on 20/May/2016

Final version resubmitted on 06/Aug/2016

Approved on 02/Set/2016 